\title{
EFFECT OF Boswellia serrata SUPPLEMENTATION IN ADDITION TO INSULIN ON GLYCEMIC CONTROL IN A DIABETIC DOG
}

\author{
Giulia Andreani ${ }^{1 *}$, Enea Ferlizza ${ }^{1}$, Elisabetta Macri', Daniela Beghelli², Gloria Isani ${ }^{1}$ \\ ${ }^{1}$ Department of Veterinary Medical Sciences, University of Bologna, via Tolara di sopra, 50, 40064 Ozzano (BO), ${ }^{2}$ School of Biosciences and \\ Veterinary Medicine, University of Camerino, Via Gentile da Varano III, 62032, Camerino (MC), Italy \\ ${ }^{*}$ Corresponding author, E-mail: giulia.andreani2@unibo.it
}

\begin{abstract}
Diabetes mellitus (DM) is a common disorder in middle-aged to older dogs. Treatment options, similar to those for humans, include insulin injection, dietary changes and exercise. Since some diabetic dogs may develop humoral immune responses to exogenous insulin resulting in treatment failure, the use of alternative medicine could represent an interesting new therapeutic strategy for DM in addition to the traditional insulin therapy. The main objective of this report was to evaluate a new therapeutic strategy for DM, based on the association of insulin injections with an orally administered extract of Boswellia serrata to improve glycemic control in a diabetic dog. A nine year old female neutered mixed breed dog diagnosed with DM was treated with increasing doses of a porcine insulin zinc suspension starting from $0.2 \mathrm{U} / \mathrm{kg}$ up to $0.6 \mathrm{U} / \mathrm{kg} q 12$ hours. Twenty weeks after the start of insulin therapy the duration of effect and glucose nadir were ideal and clinical symptoms had disappeared but hyperglycemia, although less severe, persisted. Supplementation with a dry extract from the gum-resin of Boswellia serratawas initiated, at a dosage of $15 \mathrm{mg} / \mathrm{kg} \mathrm{q} 12$ hours, to improve insulin sensitivity or possibly increasing endogenous insulin secretion. B. serrata supplementation led to good glycemic control. No side-effect or adverse reaction were observed during the study.

The present case report provides the first evidence in veterinary medicine of a positive effect of dietary supplementation with boswellic acids associated with traditional insulin therapy on glycemic control in a diabetic dog. A major pitfall of the study is the lack of a control. More extensive clinical trials are required to provide definitive evidence of $B$. serrata efficacy.
\end{abstract}

Key words: diabetes mellitus; dog; boswellic acids; glycemic control

\section{Introduction}

Diabetes mellitus (DM) is a common disorder affecting middle-aged to older dogs and characterized by hyperglycemia and glycosuria and typical clinical symptoms such as polyuria, polydipsia and weight loss $(1,2)$. Treatment options, similar to those for humans, include insulin injection, dietary changes and exercise. The classification of DM in dogs follows the

Received:28June 2016

Accepted for publication: 14 July 2017 scheme used in human medicine: canine diabetes usually resembles type 1 diabetes in humans and is characterized by permanent hypoinsulinemia and an absolute necessity for exogenous insulin to maintain control of glycemia and avoid ketoacidosis (3). Since some diabetic dogs may develop humoral immune responses to exogenous insulin resulting in treatment failure, the use of alternative medicine, including herbal extracts, represents an interesting new therapeutic strategy for DM in association with the traditional insulin therapy as reported for diabetic patients in human medicine (4). Herbal drugs usually used for human 
therapies could also be administered to pets with chronic diseases mainly to avoid collateral effects, although few studies have evaluated the efficacy of medicinal plants in animals (5). Since ancient times, frankincense, the aromatic gum resin obtained from trees of the genus Boswellia, has been used in central African countries and in the Middle East for the prevention and treatment of various illnesses, especially chronic inflammatory diseases. Boswellia serrata is a species of the Burseraceae family from India, containing boswellic acids known to present anti-inflammatory, antihepatotoxic, antioxidant, anti-hyperlipidemic and hypoglycemic properties (6). In particular, boswellic acids seem possess antileukotrienic activity, showing efficacy in human chronic inflammatory disorders like bronchial asthma (7) and Crohn's disease (8). An experimental model of multiple low-dose streptozotocin induced type 1 diabetes in mice showed that hyperglycemia results from an autoimmune reaction against pancreatic beta cells. B. serrata gum resin extracts containing boswellic acids administered to the mice prevented hyperglycemia, islet inflammation, destruction of $\beta$-cells and increases in proinflammatory cytokines (9). According to a report by Schrott et al. (2014) (4), an alcoholic extract of the $B$. serrata resin in addition to insulin, also prevented insulitis in a human patient with type 1 diabetes, leading to a decrease of tyrosine-phosphatase antibodies. Therefore, the main objective of this report was to evaluate a new therapeutic strategy for naturally occurring DM in a dog based on the association of insulin injections with an orally administered extract of $B$. serrata to improve glycemic control.

\section{Case presentation}

A nine year old female mixed breed dog weighting $18 \mathrm{~kg}$ was referred to Bologna University Veterinary Teaching Hospital with a two-month history of weight loss and enuresis, worsened by polyuria and polydipsia in the last two weeks. The bitch had been neutered at the age of seven months and was housed outdoors, fed a homemade diet and regularly vaccinated and dewormed. On physical examination, the bitch was responsive, with normal pink mucous membranes, $39^{\circ} \mathrm{C}$ rectal temperature, normal corneal transparency and no abdominal abnormalities on palpation. Abdominal ultrasound showed only a mild diffuse liver impairment. All procedures were performed under informed consent of the owners for diagnostic and/ or therapeutic purposes. Figure 1 shows a graphic timeline of the different therapeutic protocols and clinical analyses performed in this case study.

The hematological profile showed mild leucocytosis with mature neutrophilia, while the serum biochemistry profile reported the most important alterations, namely severe fasting hyperglycemia, hypertriglyceridemia, hypercholesterolemia, a moderate increase in alanine aminotransferase activity (ALT) and fructosamine and mild hypoalbuminemia. Urinalysis revealed marked glycosuria, proteinuria and albuminuria with increased urinary protein to creatinine ratio (UPC) and a mild ketonuria (Table 1).

Based on typical clinical signs and laboratory findings, DM was diagnosed and the bitch was treated with increasing subcutaneous doses of

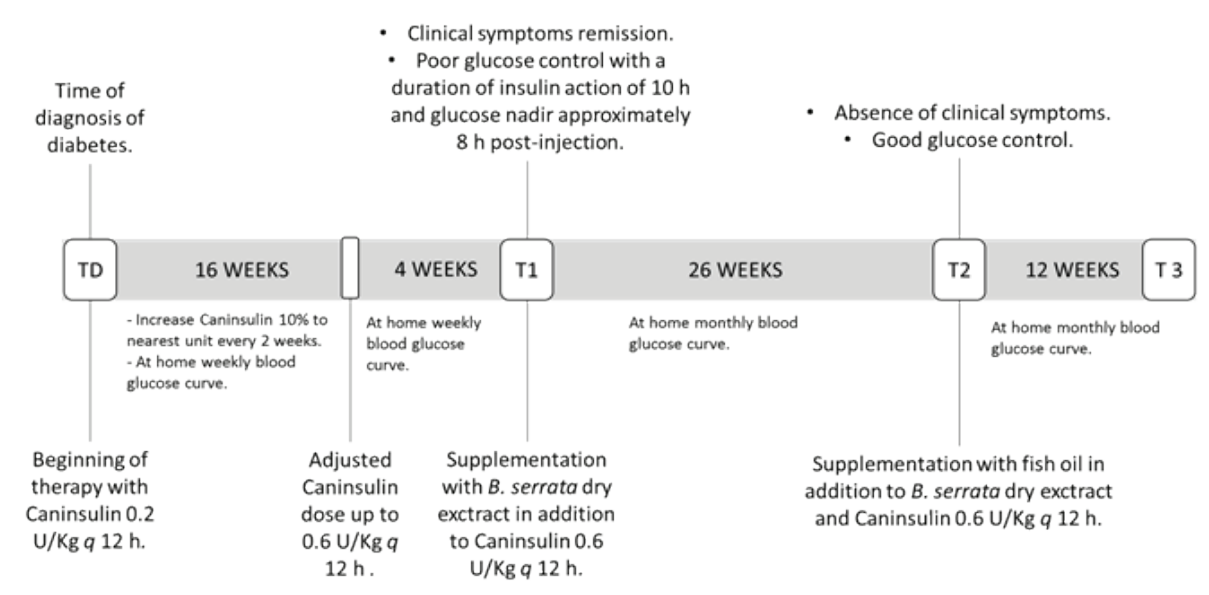

Figure 1: Graphic timeline of treatment plan and treatment goals; at time of diagnosis (TD), T1, T2 and T3 a full laboratory control, including haemato-biochemical and urine analyses, was done 
Table 1: CBC, serum biochemistry and urinalysis results for a 9 years old mixed breed dog with polyuria and polydipsia at the time of DM diagnosis (TD) and after food supplementation with $B$. serrata dry extract in addition to insulin therapy (T3)

\begin{tabular}{|c|c|c|c|}
\hline & TD & T3 & Reference range \\
\hline \multicolumn{4}{|l|}{ CBC } \\
\hline $\mathrm{RBC} \times 10^{12} / \mathrm{L}$ & 7.5 & 7.3 & $5.5-8.5$ \\
\hline HCT fraction & 0.48 & 0.52 & $0.37-0.55$ \\
\hline $\mathrm{HBG} g / \mathrm{L}$ & 175 & 174 & $120-180$ \\
\hline $\mathrm{WBC} \times 10^{9} / \mathrm{L}$ & 23.4 & 8.4 & $6-17$ \\
\hline PLT $\times 10^{9} / \mathrm{L}$ & 365 & 304 & $160-500$ \\
\hline \multicolumn{4}{|l|}{ SERUM BIOCHEMISTRY } \\
\hline Protein g/L & 69 & 68 & $56-79$ \\
\hline Albumin $\mathrm{g} / \mathrm{L}$ & 26 & 32 & $28-37$ \\
\hline Creatinine $\mu \mathrm{mol} / \mathrm{L}$ & 84 & 66 & $57-119$ \\
\hline ALT $\mu$ Kat/L & 0.97 & 2.17 & $0.33-0.92$ \\
\hline Triglycerides $\mathrm{mmol} / \mathrm{L}$ & 15.65 & 2.09 & $0.34-1.35$ \\
\hline Cholesterol mmol/L & 10.02 & 8.60 & $3.63-9.06$ \\
\hline Glucose mmol/L & 29.69 & 6.33 & $3.88-6.94$ \\
\hline Fructosamine mmol/L & 0.52 & 0.55 & $0.26-0.37$ \\
\hline \multicolumn{4}{|l|}{ URINALYSIS } \\
\hline Bilirubin $\mu \mathrm{mol} / \mathrm{L}$ & Negative & + & Negative \\
\hline Ketones mmol/L & 2.58 & Negative & Negative \\
\hline Glucose mmol/L & $>16.65$ & $>16.65$ & Negative \\
\hline Protein g/L & 0.3 & 0.3 & Negative \\
\hline $\mathrm{pH}$ & 5.5 & 6.5 & $6.5-7$ \\
\hline SG & 1040 & 1076 & $>1030$ \\
\hline WBC & + & Negative & Negative \\
\hline Blood & Negative & Negative & Negative \\
\hline Epithelial cells & + & +++ & Negative-+ \\
\hline UPC & 1.2 & 0.3 & $0.0-0.4$ \\
\hline
\end{tabular}

Table 2: Average glucose concentrations obtained from glycemic curves (blood glucose concentrations were measured before and 2, 4, 6, 8 and 10 hours after insulin injection), fasting blood glucose, blood glucose nadirs (obtained 8 hours after insulin injection), serum fructosamine and triglycerides concentrations, measured as glycemic and lipemic control indicators. Urinary protein to creatinine ratio was also determined

\begin{tabular}{ccccccc}
\hline & $\begin{array}{c}\text { Average blood } \\
\text { glucose }(\mathrm{mmol} / \mathrm{L})\end{array}$ & $\begin{array}{c}\text { Fasting blood } \\
\text { glucose }(\mathrm{mmol} / \mathrm{L})\end{array}$ & $\begin{array}{c}\text { Blood glucose } \\
\text { nadir }(\mathrm{mmol} / \mathrm{L})\end{array}$ & $\begin{array}{c}\text { Fructosamine } \\
(\mathrm{mmol} / \mathrm{L})\end{array}$ & $\begin{array}{c}\text { Triglycerides } \\
(\mathrm{mmol} / \mathrm{L})\end{array}$ & UPC \\
\hline TD & 26.20 & 29.70 & 18.31 & 0.52 & 15.65 & 1.2 \\
T1 & 23.70 & 28.36 & 17.48 & 0.52 & nd & 0.5 \\
T2 & 8.21 & 14.21 & 2.77 & 0.68 & 10.37 & 0.5 \\
T3 & 5.99 & 6.33 & 5.38 & 0.55 & 2.09 & 0.3 \\
\hline
\end{tabular}


a porcine insulin zinc suspension (Caninsulin ${ }^{\circledR}$, MSD Animal Health) starting from $0.2 \mathrm{U} / \mathrm{kg}, q$ 12 hours before feeding, up to $0.6 \mathrm{U} / \mathrm{kg}$, with an increase equal to $10 \%$ to the nearest unit every two weeks. A specific commercial restricted-fat high-fiber diet as the sole source of food was also included in the therapy. Glycemia was monitored using a Glucocard G+ home glucometer (Menarini Diagnostic) in order to obtain a weekly blood glucose curve. The glycemic control was considered good when fasting blood glucose was below 16.65 $\mathrm{mmol} / \mathrm{L}$ and the polyuria and polydipsia were absent, according to the owner's observation.

At $\mathrm{T} 1$ the bitch was re-examined. Although there was a complete remission of clinical symptoms of diabetes and the bitch gained $1.5 \mathrm{~kg}$ of weight, with a mild improvement of fasting blood glucose and blood glucose nadir, no change in serum fructosamine level was observed. Furthermore, the urinalysis revealed persistent glycosuria though with reduced proteinuria. The target results for a good glycemic control according to the AAHA diabetes management guidelines for diabetic dogs (1) were established as follows: nadir 4.44 to $8.32 \mathrm{mmol} / \mathrm{L}$, time of nadir 8 hours after insulin injection, average blood glucose < $13.87 \mathrm{mmol} / \mathrm{L}$, no single blood glucose $>16.65$ $\mathrm{mmol} / \mathrm{L}$. To further reduce hyperglycemia, the patient's diet was supplemented every 12 hours with a dry extract obtained from $B$. serrata gum resin containing $300 \mathrm{mg}$ of extract titrated to $65 \%$ in boswellic acids (15 mg/kg q 12 hours). Home monitoring was performed monthly and the owner reported a progressive improvement of glycemic control after four weeks of supplementation. A complete blood count, serum biochemistry profile and urinalysis were performed 26 weeks (T2) after the beginning of $B$. serrata supplementation to evaluate glycemic and lipemic control and the general health status of the bitch. At T2 blood glucose nadir showed a drastic drop to 2.77 $\mathrm{mmol} / \mathrm{L}$ in the absence of clinical symptoms, while fasting blood glucose was $14.21 \mathrm{mmol} / \mathrm{L}$ and UPC stably remained slightly above the references range. Blood triglyceride concentration presented a remarkable decrease, although still widely above the reference range (Table 2). For this reason, additional supplementation was introduced with $9 \mathrm{ml}$ fish oil, every 12 hours in the food. Twelve weeks (T3) after the beginning of fish oil supplementation, glycemic control showed a further decrease for both fasting blood glucose and average blood glucose and UPC also fell within the range. Blood triglyceride concentration was reduced fivefold and was very close to the reference range (Table 2). Serum ALT activity and fructosamine concentration were above the reference ranges throughout the study regardless of glycemic control (Table 1).

No side effects such as nausea, diarrhea or vomiting were observed during the study and no further serum and hematological parameters resulted altered.

\section{Discussion}

In late stage canine diabetes type 1 , loss of $\beta$-cell function is irreversible and lifelong insulin therapy is mandatory to maintain glycemic control of the diabetic state $(10,11)$. Despite the pharmacotherapy approved for use in diabetic dogs, based on the administration of a porcine insulin zinc suspension (12) and the existence of other types of insulin tested in dogs $(13,14)$, it is still difficult to achieve adequate glycemic control in many diabetic canine patients, due to many causes such as insulin resistance or insulin-induced hyperglycemia. Most of the diabetic dogs are well controlled already at $0.5 \mathrm{U} /$ $\mathrm{Kg} q 12$ hours (1). Also in the case reported in this paper, therapy based on $0.6 \mathrm{U} / \mathrm{kg} q 12$ hours of a porcine insulin zinc suspension resulted in the disappearance of clinical symptoms with an ideal duration of therapeutic effect (10 hours) and time of glucose nadir ( 8 hours post-injection). However, hyperglycemia, tough less severe, and persistent glycosuria were still present. Glycosuria in dogs typically develops when blood glucose concentration exceeds approximately $11.1 \mathrm{mmol} / \mathrm{L}$ and since average blood glucose in diabetic dogs should be less than $13.87 \mathrm{mmol} / \mathrm{L}$, glycosuria may occur also in well controlled diabetic patients (1). In the present study, to achieve a better glycemic control, rather than increasing the dose of insulin, a food supplementation with a dry extract from $B$. serrata was introduced. This choice has the advantage to minimize the risk of hypoglycemia, which may often results in dogs with insulin excess or after excessive and strenuous exercise and to maintain the benefits obtained with the therapy based on $0.6 \mathrm{U} / \mathrm{kg} q 12$ hours of insulin.

Different medicinal plants have been found to have a hypoglycemic effect both in normal 
and diabetic human patients (15). Among herbal drugs, dry extract of the $B$. serrata gum resin have been used in traditional medicine for a variety of therapeutic purposes (16) without adverse effects or interferences with other drugs reported to date in experimental animals and humans $(17,18$, 19). Boswellic acids, including O-acetyl-11-keto $\beta$ boswellic acid (AKBA) and 11-keto- $\beta$-boswellic acid (KBA), present in $B$. serrata gum resin, are novel, specific inhibitors of 5-lipoxygenase with a wide therapeutic potential (20). An alcoholic extract of $B$. serrata gum resin and two of its active compounds, AKBA and KBA, were recently reported to prevent hyperglycemia in multiple low-dose streptozotocin-induced diabetic mice as an animal model of type 1 DM, possibly by suppressing the production/action of proinflammatory cytokines and preventing insulitis in an autoimmune process $(21,9)$. Moreover, Schrott et al. (4) observed that treatment with $B$. serrata extract in a human patient with latent autoimmune type 1 diabetes led to a significant decrease of IA2 antibodies, a typical marker of autoimmune diabetes used in human medicine. There is also evidence that $B$. serrata supplementation with $900 \mathrm{mg} /$ die for six weeks in human diabetes type 2 produces a remarkable decrease in fasting blood glucose (22). In the present study, clinical symptoms showed the typical features of canine diabetes and the diagnosis was achieved at a late stage. Therefore, it was not possible to clearly understand the etiopathogenesis and to classify the type of DM by assessing peptide C level to confirm an endogenous secretion of insulin, and/ or by assessing the presence of autoantibodies to evaluate an autoimmune reaction. However, the good response to insulin therapy let us suppose that the dog was affected by type $1 \mathrm{DM}$. The hypoglycemic effect of $B$. serrata extract, administered in addition to insulin therapy, was evident and probably due to the improvement of a possible remaining endogenous insulin secretion through its antinflammatory action in an autoimmune process. Moreover, B. serrata supplementation in human patients affected by diabetes type 2 produces a significant decrease in blood cholesterol, LDL, fructosamine, ALT and AST activities and increased insulin levels (22). ALT activity in our case was over the reference range throughout the study, as already described for different hepatic enzyme activities in diabetic dogs probably due to hepatic lipidosis (23).
However, the increased ALT activity was not accompanied by clinical symptoms and it may not be associated with progressive liver damage. A randomized clinical trial study in human type 2 diabetic patients, treated with $400 \mathrm{mg} /$ die of $B$. serrata powder reported significantly lower glucose, HbA1c, insulin, total cholesterol, LDL and triglycerides levels with respect to a placebo group (24). In addition to its hypoglycemic effect, $B$. serrata could be used also as an anti-hyperlipidemic agent in diabetic patients (25), although in the present study an evident drop of serum triglycerides was obtained only after the administration of fish oil, as previously reported (26).

Despite the improvement in the glycemic control, the serum fructosamine concentration remained above the reference range throughout the study. This discrepancy between fructosamine and glucose serum concentration has already been reported in diabetic dogs $(13,27)$ and may be due to the delay between change in control of glycemia and change in blood glycated protein concentration. However, also specific canine genetic factors may influence variations in serum fructosamine concentration unrelated to glycemia as reported in Belgian Shepherds (28).

\section{Conclusion}

To the best of our knowledge, the only insulin preparation approved for use in dogs with DM is a porcine insulin zinc suspension that does not always provide optimal glycemic control. On the other hand, most DM dogs are type I insulin-dependent and oral hypoglycemic drugs are usually ineffective or accompanied by sideeffects. The present case study provides the first evidence in veterinary medicine of a positive effect of dietary supplementation with dry $B$. serrata extract associated with traditional insulin therapy on glycemic and lipemic control in a dog with naturally occurring DM. The use of $B$. serrata extract in many inflammatory diseases did not produce any side-effects $(6,29)$ and could be a cheap and safe DM treatment option in addition to insulin therapy, when insulin alone cannot achieve good glycemic control.

The major pitfall of this study is the lack of a control case. A more extensive pharmacological study and interventional prospective clinical trials are needed to clarify the mechanism of 
action of $B$. serrata extracts and to provide a definitive evidence of their efficacy and safety in the treatment of diabetes mellitus in dogs.

\section{Acknowledgements}

The authors are thankful to Dr. Federico Fracassi for helpful scientific discussion and to Dr. Maurizio Scozzoli and APA-CT-Greenvet srl (Forli, Italy) for providing $B$. serrata extracts free of charge.

\section{References}

1. Rucinsky R, Cook A, Haley S, Nelson R, Zoran DL, Poundstone M. AAHA Diabetes management guidelines for dogs and cats. J Am Anim Hosp Assoc 2010; 46: 215-24.

2. Nelson RW, Reush CE. Animal models of disease: classification and etiology of diabetes in dogs and cats. J Endocrinol 2014; 222(3): eT1-9. http://dx.doi.org/10.1530/JOE-14-0202

3. Catchpole B, Kennedy LJ, Davison LJ, Ollier WE. Canine diabetes mellitus: from phenotype to genotype. J Small Anim Pract 2008; 49: 4-10.

4. Schrott E, Laufer S, Lammerhofer M, Ammon HPT. Extract from gum resin of Boswellia serrata decrease IA2-antibody in a patient with "Late onset Autoimmune Diabetes of the Adult" (LADA). Phytomedicine 2014; 21(6): 786.

5. Russo R, Autore G, Severino L. Pharmaco-toxicological aspects of herbal drugs used in domestic animals. Nat Prod Commun 2009; 4(12): 1777-84.

6. Hartman RM, Morgan Martins MI, Tieppo J, Fillmann HS, Marroni NP. Effect of Boswellia serrata on antioxidant status in an experimental model of colitis rats induced by acetic acid. Dig Dis Sci 2012; 57: 2038-44.

7. Gupta I, Gupta V, Parihar A, et al. Effects of Boswellia serrata gum resin in patients with bronchial asthma: results of a double-blind, placebo-controlled, 6-week clinical study. Eur J Med Res 1998; 17: 511-4.

8. Gerhardt H, Seifert F, Buvari P, Vogelsang $\mathrm{H}$, Repges R. Therapy of active Crohn disease with Boswellia serrata extract H 15. Z Gastroenterol. 2001; 39: 11-7.

9. Shehata AM, Quintanilla-Fend L, Bettio S, et al. 11-Keto- $\beta$-boswellic acids prevent development of autoimmune reactions, insulitis and reduce hy- perglycemia during induction of multiple low dose streptozotocin (MLD-STZ) diabetes in mice. Horm Metab Res 2015; 47: 463-9.

10. Verkest KR, Rand JS, Flemann LM, Morton JM. Spontaneously obese dogs exibit greater post-prandial glucose, triglyceride and insulin concentration than lean dogs. Domest Anim Endocrinol 2012; 42(2): 103-12.

11. Gilor C, Niessen SJM, Furrow E, DiBartola SP. What's in a name? Classification of diabetes mellitus in veterinary medicine and why it matters. J Vet Intern Med 2016; 30: 927-40.

12. Monroe WE, Laxton D, Fallin EA, et al. Efficacy and safety of a purified porcine insulin zinc suspension for managing diabetes mellitus in dogs. J Vet Intern Med 2005; 19: 675-82.

13. Fracassi F, Boretti FS, Sieber-Ruckstuhl NS, Reusch, CE. Use of insulin glargine in dogs with diabetes mellitus. Vet Rec 2012; 170(2): 52.

14. Fracassi F, Corradini S, Hafner M, Boretti FS, Sieber-Ruckstuhl NS, Reusch, CE. Detemir insulin for the treatment of diabetes mellitus in dogs. J Am Vet Med Assoc 2015; 247: 73-7.

15. Ezuruike UF, Prieto JM. The use of plants in the traditional management of diabetes in Nigeria: pharmacological and toxicological considerations. J Ethnopharm 2014; 155: 857-924.

16. Poekel D, Werz O. Boswellic acids: biological actions and molecular targets. Curr Med Chem 2006; 13: 3359-69.

17. Singh GB, Atal CK. Pharmacology of an extract of salai guggal ex-Boswellia serrata, a new non-steroidal anti-inflammatory agent. Agent Actions 1986; 18: 407-12.

18. Ammon HPT. Modulation of the immune system by Boswellia serrata extracts and boswellic acids. Phytomedicine 2010; 17: 862-7.

19. Beghelli D, Isani G, Roncada P, et al. Antioxidant and ex vivo immune system regulatory properties of Boswellia serrata extracts. Oxid Med Cell Longev 2017; 2017: eID 7468064 (10 pp.) https://doi.org/10.1155/2017/7468064

20. Sharma A, Chhikara S, Ghodekar SN, et al. Phytochemical and pharmacological investigations on Boswellia serrata. Pharmacogn Rev 2009; 3: 206-15.

21. Shehata AM, Quintanilla-Fend L, Bettio S, Singh CB, Ammon HPT. Prevention of multiple low-dose streptozotocin (MLD-STZ) diabetes in mice by an extract from gum resin of Boswellia serrata (BE). Phytomedicine 2011; 18: 1037-44.

22. Ahangarpour A, Heidari H, Fatemeh RAA, 
et al. Effect of Boswellia serrata supplementation on blood lipid, hepatic enzymes and fructosamine levels in type 2 diabetic patients. J Diabetes Metab Disord 2014; 13: 29-37.

23. Hess RS, Saunders HM, Van Winkle TJ, Shofer FS, Washabau RJ. Clinical, clinicopathologic, radio-graphic, and ultrasonographic abnormalities in dogs with fatal acute pancreatitis: 70 cases (1986-1995). J Am Vet Med Assoc 1998; 213: 665-70.

24. Azadmehr A, Ziaee A, Ghanei L, et al. A randomized clinical trial study: anti-oxidant, anti-hyperglycemic and anti-hyperlipidemic effects of Olibanum Gum in type 2 diabetic patients. Iran J Pharm Res 2014; 13: 1003-9.

25. Alam M, Khan H, Samiullah L, Siddique KM. A review on phytochemical and pharmacological studies of Kundur (Boswellia serrata Roxb ex Colebr.)-A Unani drug. J App Pharm Sci 2012; 2(3): 148-56.
26. Xenoulis PG, Steiner JM. Lipid metabolism and hyperlipidemia in dogs. Vet $\mathrm{J} 2010 ; 183: 12-21$.

27. Briggs CE, Nelson RW, Feldman EC, E1liott DA, BVSc, Neal LA. Reliability of history and physical examination findings for assessing control of glycemia in dogs with diabetes mellitus: 53 cases (1995-1998). J Am Vet Med Ass 2000; 217 : 48-53.

28. Forsberg SKG, Kierkzac M, Ljungvall I, et al. The Shepherds tale: a genome wide study across 9 dogs breeds implicates two loci in the regulation of fructosamine serum concentration in Belgian shepherds. Plos ONE 2015; 10(5): e0123173 (17 pp.) http://dx..doi.org/10.1371/ journal.pone.0123173 (April 2016)

29. Reichling J, Schmökel HS, Bucher S, Saller R. Dietary support with Boswellia resin in canine inflammatory joint and spinal disease. Schweiz Arch Tierheilkd 2004; 146: 71-9.

\title{
VPLIV DODAJANJA BOSVELIJE (Boswellia serrata) OB ZDRAVLJENJU Z INZULINOM NA UREJANJE RAVNI GLUKOZE V KRVI PRI PSU S SLADKORNO BOLEZNIJO
}

\author{
G. Andreani, E. Ferlizza, E. Macrì, D. Beghelli, G. Isani
}

Povzetek: Sladkorna bolezen oz. diabetes mellitus (DM) je pogosta motnja pri psih v srednjih letih in starejših psih. Možnosti zdravljenja, ki so podobne kot pri ljudeh, vključujejo dodajanje inzulina, spremembe v prehrani in telesno aktivnost. Ker lahko nekateri psi s sladkorno boleznijo razvijejo imunski odziv na dodajanje inzulina, kar lahko vodi do neuspešnega zdravljenja, lahko uporaba alternativne medicine predstavlja zanimivo novo metodo zdravljenja DM poleg tradicionalnega zdravljenja zinzulinom. Glavni cilj raziskave je bil ovrednotiti novo metodo zdravljenja DM, ki temelji na hkratnem dodajanju inzulina in peroralnem dodajanju izvlečka bosvelije (Boswellia serrata) za izboljšanje urejanja ravni glukoze v krvi pri psu s sladkorno boleznijo. Devet let stara sterilizirana samica mešane pasme, ki je bila diagnosticirana s sladkorno boleznijo, je bila zdravljena z naraščajočimi odmerki suspenzije prašičjega inzulina in cinka (od 0,2 E/kg do 0,6 U/kg), ki jih je dobivala vsakih 12 ur. Dvajset tednov po začetku zdravljenja zinzulinom so bili učinki in najnižja vrednost izmerjene glukoze v normalnih mejah vrednosti, klinični simptomi so izginili, le hiperglikemija je bila še vedno prisotna, vendar pa je bila manj resna. Dodatek suhega izvlečka iz gumijeve smole bosvelije BosweIlia serrata v odmerku $15 \mathrm{mg} / \mathrm{kg}$ vsakih 12 ur je povečal občutljivost na inzulin oz. morebitne preostanke endogenega izločanja inzulina. Dodatek B. serrataje pozitivno vplival na nadzorovanje sladkorne bolezni. Med zdravljenjem niso bili opaženi stranski ali nezaželeni učinki. Poročilo o opisanem primeru vsebuje prve dokaze o pozitivnem učinku prehranskega dopolnilaz bosveličnimi kislinami v veterinarski medicini, povezanimi z običajnim zdravljenjem z inzulinom, pri nadzoru glukoze v krvi pri psu s sladkorno boleznijo. Najbolj neugoden del te študije je odsotnost kontrole. Za zagotovitev dokončnega dokaza o učinkovitosti B. serrata so potrebni obsežnejši klinični poskusi.

Ključne besede: diabetes mellitus; pes; bosvelična kislina; nadzor sladkorne bolezni 